\title{
Application of Building Workers Services in Facing Industrial Revolution 4.0
}

\author{
Izwan Amsyar ${ }^{1}$, Ethan Cristhopher ${ }^{2}$, Untung Rahardja ${ }^{3}$, Ninda Lutfiani ${ }^{4}$, Agung Rizky ${ }^{5}$ \\ Faculty of Science \& Technology, Raharja University Jl. Jenderal Sudirman No. 40 Modern \\ Cikokol Tangerang 15117 \\ e-mail:amsyarizwan@yahoo.com, ethancristho@yahoo.com, untung@raharja.info, \\ ninda@raharja.info, agungrizky@raharja.info
}

To cite this document:

Amsyar, I. ., Cristhopher, E. ., Rahardja, U. ., Lutfiani, N. ., \& Rizky, A. (2021). Application of Building Workers Services in Facing Industrial Revolution 4.0. Aptisi Transactions on Technopreneurship (ATT), 3(1), 32-41.

DOI: https://doi.org/10.34306/att.v3i1.117

\begin{abstract}
The services of skilled construction workers are only known around them in the sense that they are not yet widespread in the community, therefore an application is needed that can help construction workers services and can make it easier for the wider community to find construction workers services. The purpose of this research is to build applications as building laborer services based on android and to make construction workers able to compete in this era of industrial revolution 4.0. The method used in this research is the waterfall methodology, where in this methodology each stage of the research is carried out sequentially, starting from the stages of analysis, design, writing program code, testing, and maintenance. This application uses Adobe Illustrator, AirDroid, Android Studio and Sublime Text, but the problem in this research is that it is very difficult to find experienced and professional construction workers and most of these construction workers do not understand the digital world so it is difficult to develop this research in old school community (do not understand the world of technology today).
\end{abstract}

Keywords: Society, Application, Building Worker services.

\section{Introduction}

The rapid advancement of technology and information has had a considerable impact on lift [1] The growth of existing technological advances is so easily felt in everyday life. This world has many skilled and professional builders [2]. But not many people are aware that the wealth of human resources is actually around the community. Wealth is a builder. Builders may often be underestimated. This assumption is certainly not true because a craftsman has many benefits, one of which is as an aesthetic element or beauty in the construction or renovation of a house. Besides having an aesthetic element, a professional craftsman also has a high selling value because not everyone can do it. For this reason, various kinds of experts and their expertise need to be introduced to the public. Various themes and platforms of service applications have been created. Many business institutions and developers have created applications with related themes [3].

The application product is still limited to providing information / services in ordering building design services and online transportation and has not touched the services of a builder [4]. In terms of development, Indonesia is a country that has experienced quite rapid 
development. The problem that is still often encountered is the difficulty of finding experienced and trusted builders. The things that are considered by the community in choosing a handyman are how many hours they fly and the quality of their work. Therefore it is necessary to provide a mobile application that is able to connect builders and the public through a smartphone device [5] [6]. This study aims to build an application of building services to the community. This android-based application that is able to provide services includes data collection of artisans along with their portfolio information, and handyman service booking transactions [7] [8].

\section{Research Method}

E In making coolie service applications, the research method used is the waterfall method including analysis, design, writing program code, testing and maintenance [9]. In this section, it will be discussed more clearly about the general description of the system, system design, interface design, scenario design and testing [10] [11].

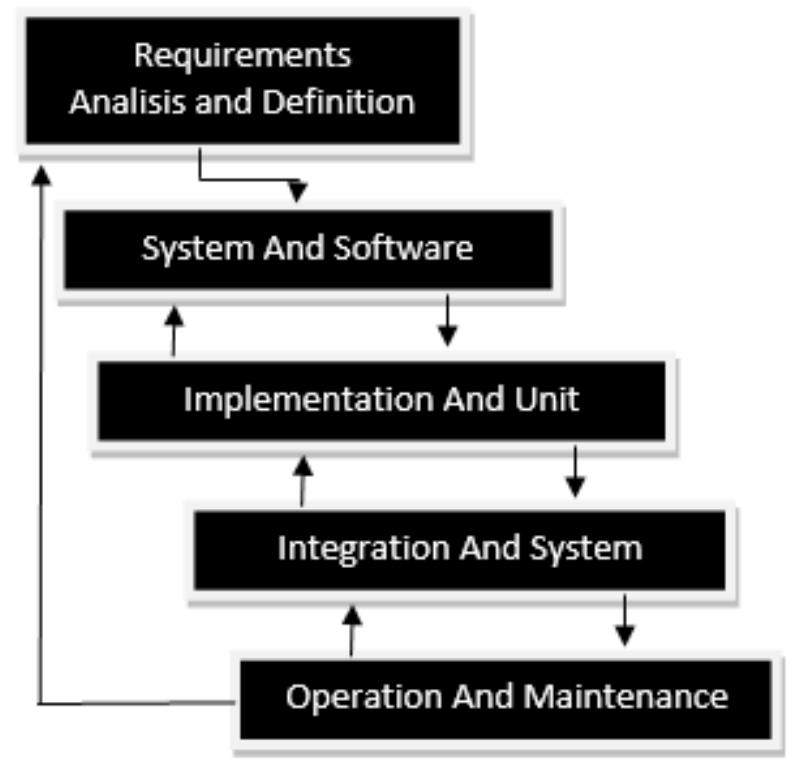

Figure 1. Waterfall System Development

The following is an explanation of the stages in the image above :

Requirements analysis is a constraint, and the objectives are explained in detail in order to have a function as the content of the quality system [12]. System and software design is the system software and hardware requirements in shaping the design that will be made. Implementation and unit testing is a program design that will test the results to meet the desired requirements.

Integration and system testing is a test that functions to adjust the system that has been created. Operation and maintenance is a stage that involves the whole thing that has happened or will occur, usually a long time in terms of reducing errors in the system and improving the program, as well as being an excess in solving problems [13]. 


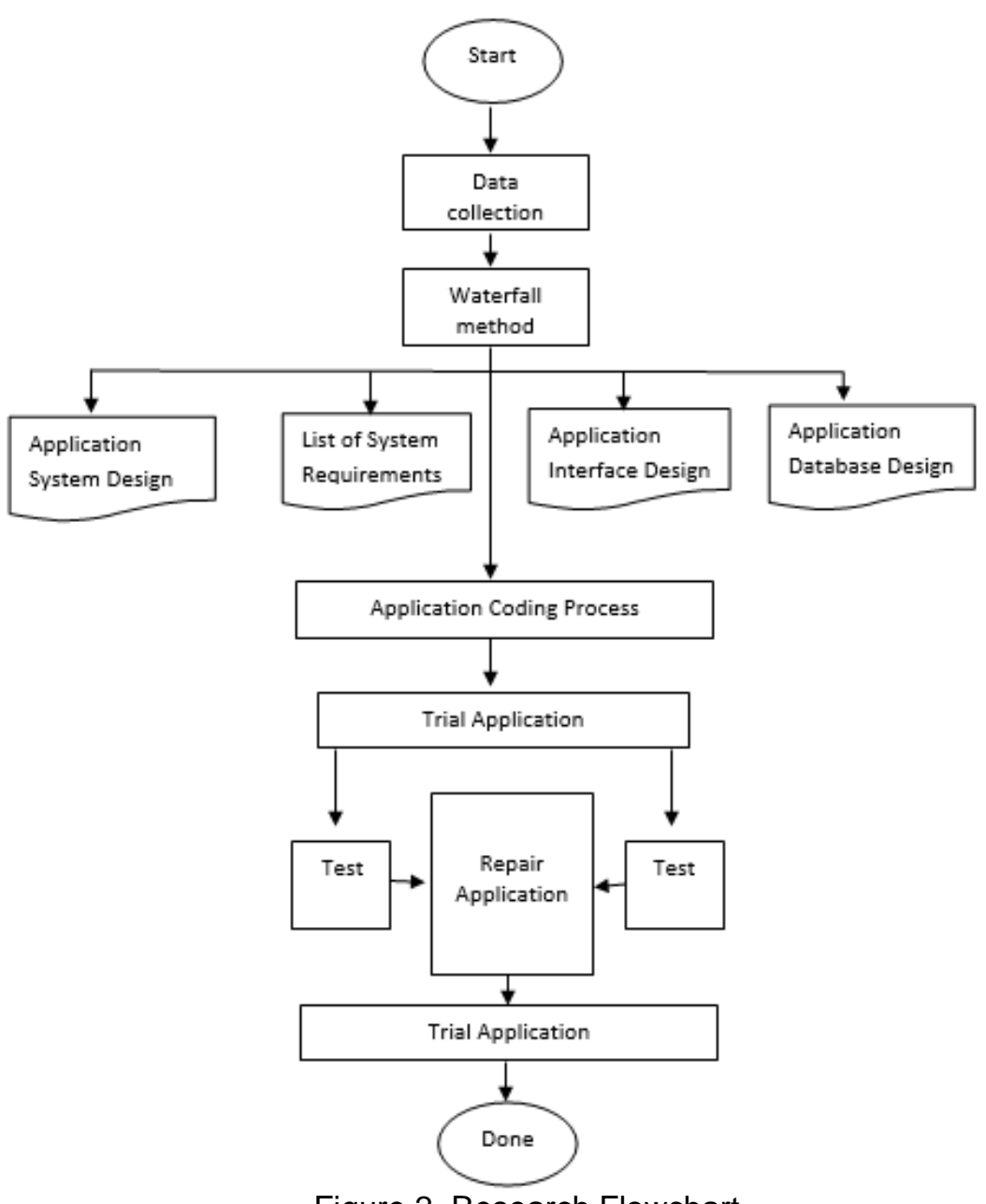

Figure 2. Research Flowchart

The flowchart above is the flow that will be carried out in this study.

\subsection{Literature Review}

The author conducts library research to obtain theoretical aspects in collecting data and information through reference books, scientific journals and other material related to the issues reviewed in the preparation of this research [14] [15].

System Overview FastKul application as a builder service provider application is built using the Java programming language in the Android platform [16]. An overview of the Fastkul system is shown in Figure 3 [17]. There are two users of the system, namely the community (customer) and the handyman as a service provider. All transactions are processed in the Fastkul application using the internet and Android smartphones [18] [19].

System Design System design is a stage to identify all system requirements. In system design, use case diagrams are used to provide a functional description of the system. The use case diagram is shown in Figure 3 below [20]. 


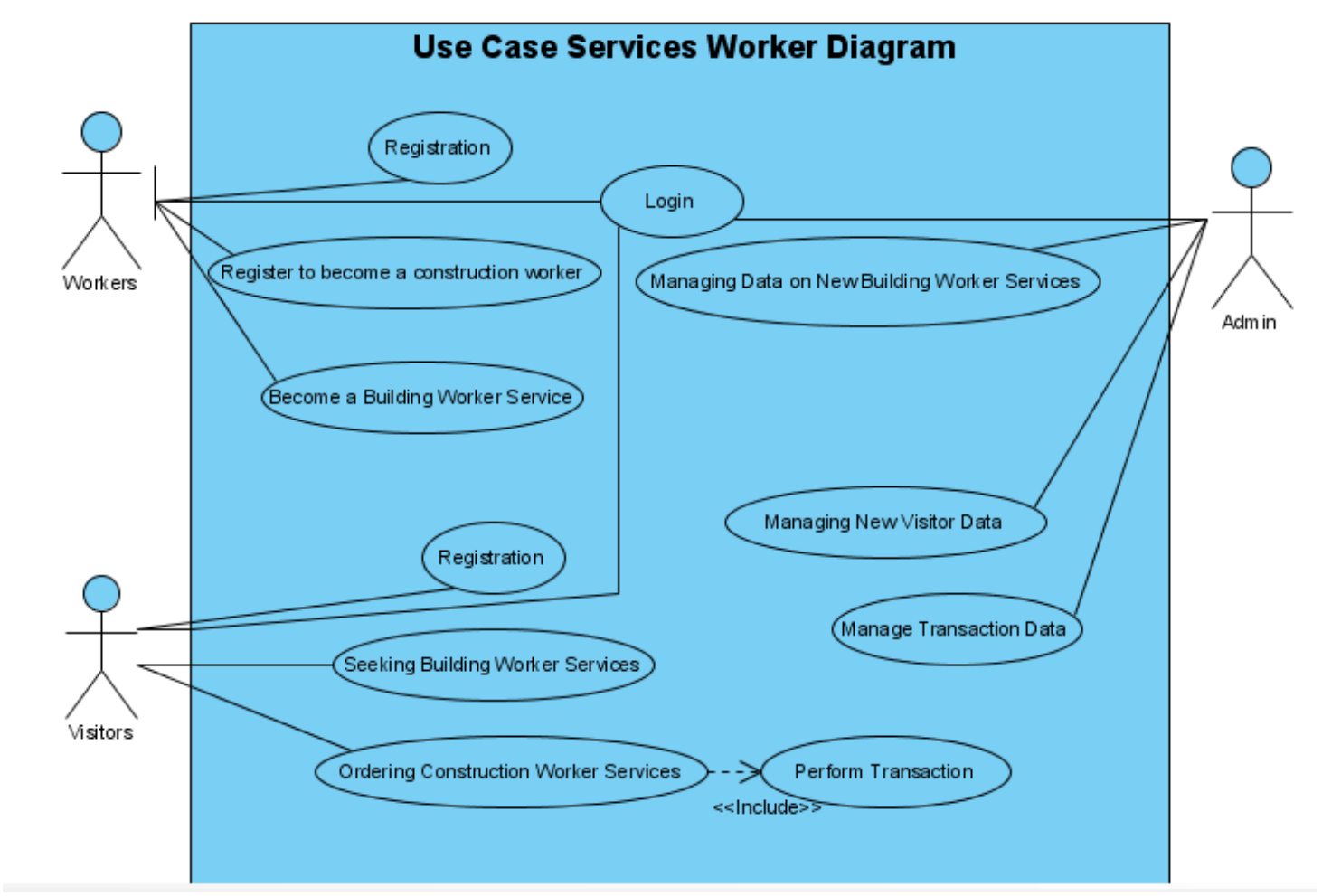

Figure 3. Use Case Services Worker Diagram

Interface Design Interface design is a stage to provide an overview of the appearance of applications that will be used by users [21] [22]. The number of interfaces for users is the start page, the login page, the user register page, the main menu page, the handyman message page [23]. The admin page interface includes the admin login and the admin main page. The interface for a handyman includes the builder's page, the builder's register page, and the master's main menu page [24].

Start Page Design The Start Page Design is shown in Figure 2. This page can be used for all users including the general public, admin, and handyman. The buttons provided are login, register, handyman register, and exit [25]. 


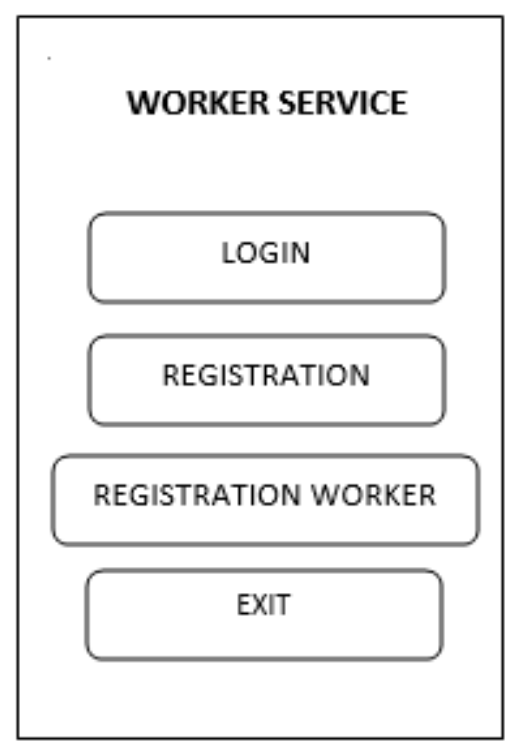

Figure 4. Start Page Design

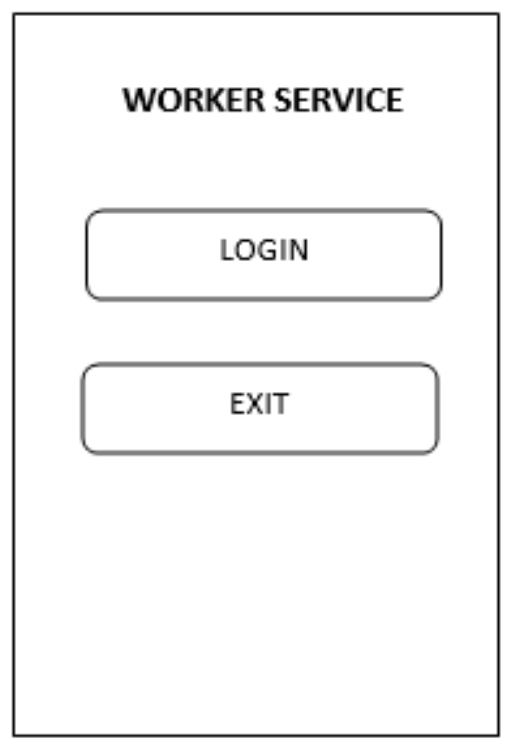

Figure 5. Login Page Design

On the Start Page or picture 2, you can see that there are 4 buttons namely the Login, Register, Register and Exit Register buttons. The Login button functions to go to the Main Menu page, the Register button functions to register as a user to be able to Login, the Exit button functions to exit the game [26] [27].

Designing a User Login Page. The design of the User Login Page is shown in Figure 3. On the User Login Page two buttons will appear namely login and exit, the login button functions to enter the next page, and the exit button functions to exit the application [28].

Designing the User Register. The design of the User Register Page is shown in Figure 4. On the User Register Page, it can be seen that there is a username text field, a password text field, an email text field, an age text field and an OK button that must be filled if you want to log in and enter the Main Menu.

\section{Findings}

Context Diagram is a general description of the system, by making a context diagram makes it easy for a programmer to make an application, so that the program is made as expected by an analyst [29].

\subsection{Problem}

In this section, before entering the Research implementation section, you can write down the problems that you find during conducting research. and how you can solve the problem [30]. Regarding the problem in this research, namely the difficulty of finding customers and construction workers for the first time, because there are still not many people who know it widely and require a large amount of money to realize this research. The solution to this problem will be solved to find the best way by making proposals to other companies to invest and many things by explaining that if this research can be implemented, it will have a very good impact for the wider community, if this method is successful, it is not difficult to introduce the results of this research by means of social media, and advertised in various media [31]. 


\subsection{Research Implementation}

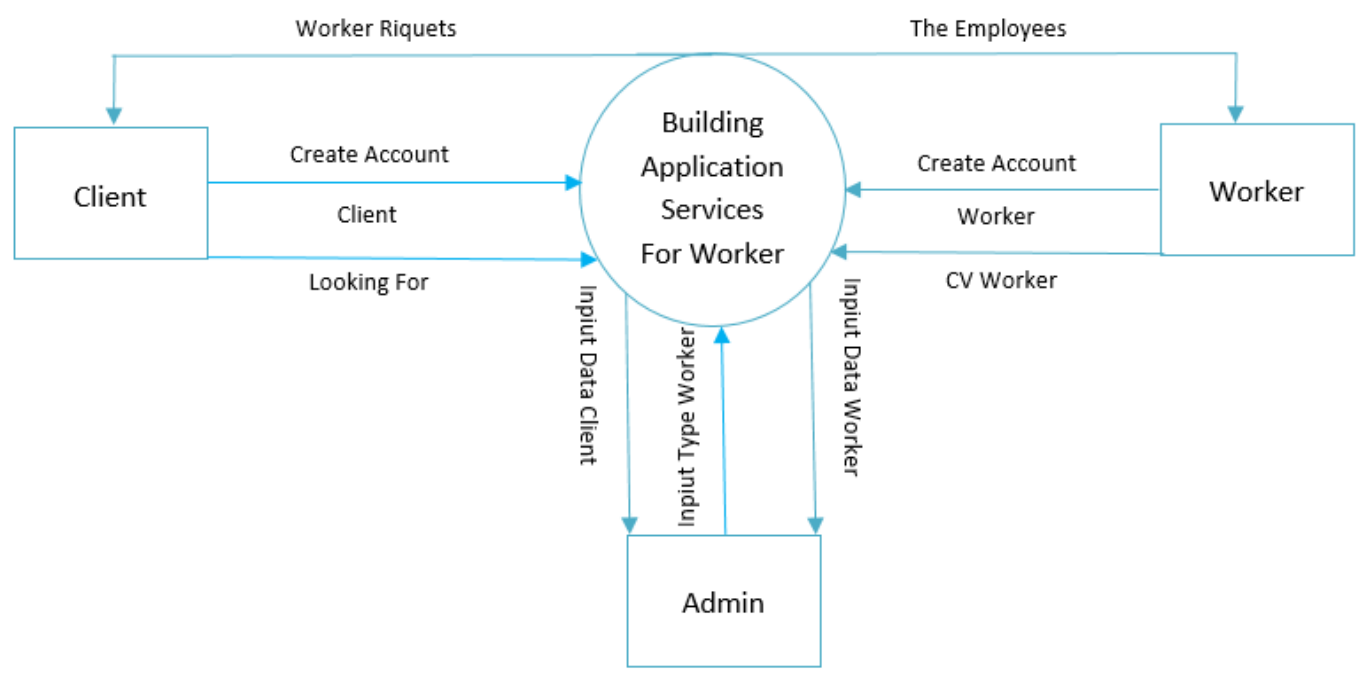

Figure 6. Data Flow Diagram DFD level 1/Context Diagram

Data Flow Diagram (DFD) Level 1 is the result of the elaboration of DFD level 1, which describes each process that exists at DFD level 1.

The following are the database tables in this study:

Table 1. Worker Service Database

\begin{tabular}{|l|l|l|}
\hline NO & COLUMN/FIELDS & TYPE \\
\hline 1 & No Transaction & Varchar \\
\hline 2 & Date & Date \\
\hline 3 & Id User & Int \\
\hline 4 & Status & Varchar \\
\hline
\end{tabular}

The Tb_Worker Services database contains 4 data, the first is No_Transaction which functions to verify / or store a transaction data that has been carried out, the second date, this date is to provide a date for each transaction and every thing that is done by the admin / service. The third Id_User is a primary key that connects the 4 data in the table. And finally the 4th status is data that provides a description of every incident carried out by the worker / admin service. 
Table 2. Client Database

\begin{tabular}{|l|l|l|}
\hline NO & COLUMN/FIELDS & TYPE \\
\hline 1 & Code_User & Int \\
\hline 2 & Name & Varchar \\
\hline 3 & Type Of Work & Varchar \\
\hline 4 & No_Telephone & Varchar \\
\hline 5 & Password & Varchar \\
\hline 6 & Type_Account & Varchar \\
\hline
\end{tabular}

In the Tb_Client database contains 6 data, first code_user is client data in the form of an account that has registered in the construction labor service application which connects all data contained in the tb_client data table. The second name is the data that contains the name of the client. The three types of workers are data to choose what types of workers are in the construction labor service application. Fourth No telpon is a data that contains the telephone number of the client. The fifth password is data that contains a password from the client. And finally the 6 Type_account, is data that contains the type of account that has been filled in by the client.

Table 1. Worker Database

\begin{tabular}{|c|l|l|}
\hline NO & COLUMN/FIELDS & \multicolumn{1}{|c|}{ TYPE } \\
\hline 1 & Code_Worker & Int \\
\hline 2 & Name_Worker & Varchar \\
\hline 3 & Address & Varchar \\
\hline 4 & No_Telephone & Varchar \\
\hline 5 & Password & Varchar \\
\hline
\end{tabular}

Name_worker, is data that contains the name of the construction laborer service. Third, Address, is a data that contains an address of the construction laborer service. Fourth No telephone is data containing the telephone number of the construction worker service. The fifth password is data containing a password from construction workers' services.

In this system, the required tables are 3 types of table_work services, table_user, and table_work.

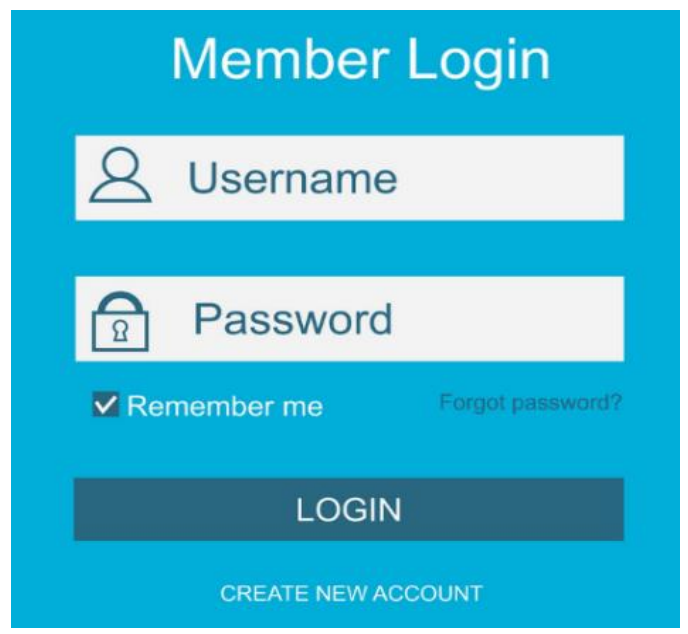

Figure 7. Menu Login 
The appearance of the application can be seen in the picture, where we have to log in first, if the login is not owned, you must register first.

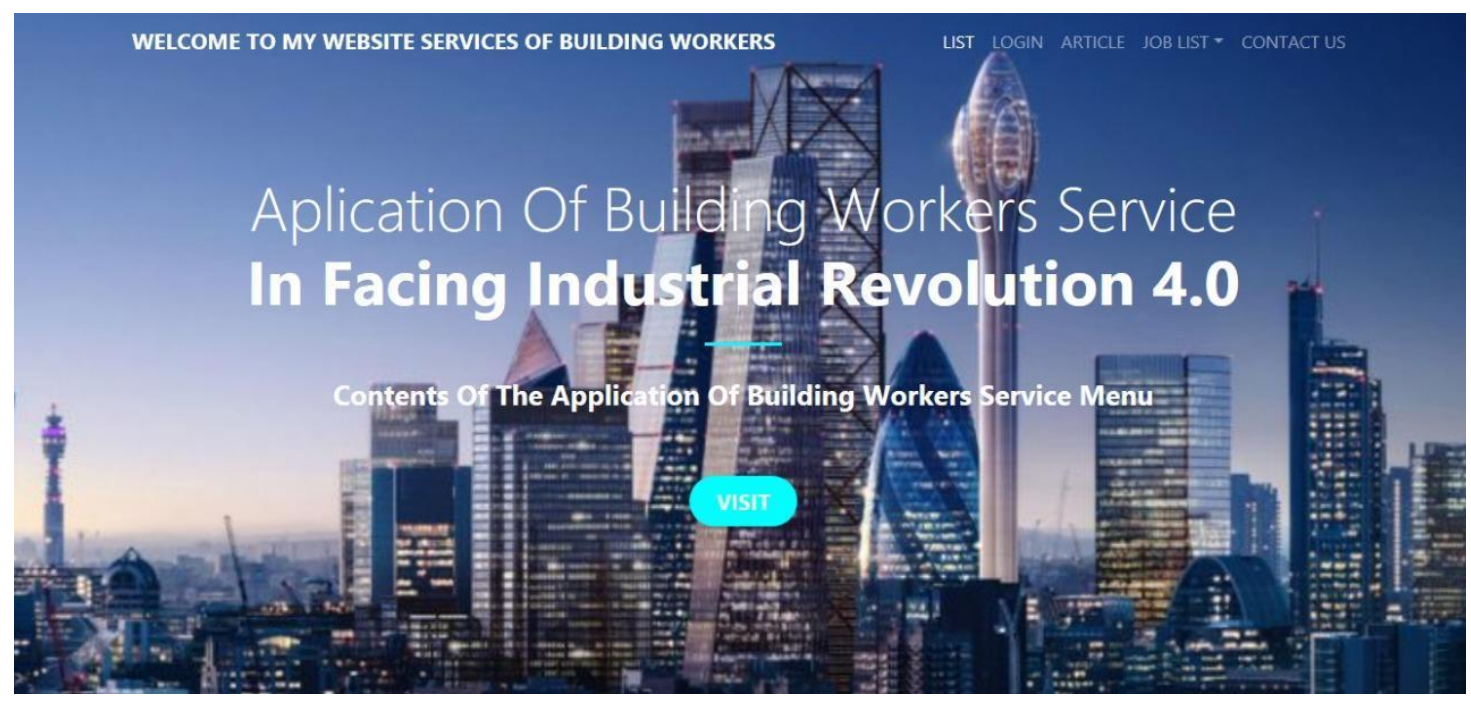

Figure. 8 Menu Dashboard The following are the results of the initial appearance of the workers services application site.

\section{Conclusion}

In the research, the application of building labor services based on Android will more or less be made like this, with the application of the android-based construction laborer service application will help construction workers services and can make it easier for the wider community to find construction workers services and make construction workers able to compete in era of this 4.0 industrial revolution [32] [33].

The problem faced in this research is the amount of costs in realizing this research, so it requires various investors in realizing this research [34].

By implementing this research throughout the wider community will have a positive impact on manual workers and service users of construction workers.

\section{References}

[1] M. Faid and H. Bahar, "APLIKASI BANTU RAKYAT BERBASIS ANDROID DALAM MENGHADAPI REVOLUSI INDUSTI 4.0," in Seminar Nasional Sistem Informasi (SENASIF), 2019, vol. 3, no. 1, pp. 2015-2022.

[2] M. Y. Simargolang and N. Nasution, "Aplikasi Pelayanan Jasa Laundry Berbasis WEB (Studi Kasus: Pelangi Laundry Kisaran)," JurTI (Jurnal Teknol. Informasi), vol. 2, no. 1, pp. 9-14, 2018.

[3] A. Atikah and A. Huda, "PERANCANGAN APLIKASI HOME SERVICE MENGGUNAKAN PROGRESSIVE WEB APPLICATION," VoteTEKNIKA J. Vocat. Tek. Elektron. dan Inform., vol. 7, no. 3, pp. 85-93, 2019.

[4] D. J. Surjawan and A. W. R. Emanuel, "Perhitungan Biaya Pembangunan Rumah dengan Estimasi Waktu, Material, dan Jasa Pekerja," 2013.

[5] V. G. Venkatesh, K. Kang, B. Wang, R. Y. Zhong, and A. Zhang, "System architecture for blockchain based transparency of supply chain social sustainability," Robot. Comput. Integr. Manuf., vol. 63, p. 101896, 2020.

[6] S. Sutrisno and A. Ajie Sajidin, "Gadgetku.id application as a Solution to Facilitate the Fulfillment of All Gadget Needs today (case study: area Tangerang Banten)," Aptisi 
Trans. Technopreneursh., vol. 1, no. 1, pp. 52-63, 2019, Accessed: Apr. 05, 2019. [Online]. Available: https://pandawan.aptisi.or.id/index.php/att/article/view/25.

[7] A. Y. A. Firmansyah, "TA: Rancang Bangun Aplikasi Rencana Anggaran Biaya Dalam Pembangunan Rumah." STIKOM Surabaya, 2013.

[8] P. O. A. Sunarya and N. Lutfiani, "Analisis Sistem Sertifikasi Profesi Untuk Pengembangan Kompetensi Mahasiswa," ADI Bisnis Digit. Interdisiplin J., vol. 1, no. 1, pp. 70-77, 2020.

[9] F. N. Wowor, B. F. Sompie, D. R. O. Walangitan, and G. Y. Malingkas, "Aplikasi Microsoft Project dalam Pengendalian Waktu Pelaksanaan Pekerjaan Proyek," J. Sipil Statik, vol. 1, no. 8, 2013.

[10] A. Rifai and Y. P. Yuniar, "Penerapan Metode Waterfall Dalam Perancangan Sistem Informasi Ujian Pada SMK Indonesia Global Berbasis Web," J. Khatulistiwa Inform., vol. 7, no. 1, 2019.

[11] I. D. Lesmono, "Rancang Bangun Sistem Informasi Penjualan Sepatu Berbasis Website Dengan Metode Waterfall," Swabumi, vol. 6, no. 1, pp. 55-62, 2018.

[12] J. W. Janis, D. J. Mamahit, B. A. Sugiarso, and A. M. Rumagit, "Rancang Bangun Aplikasi Online Sistem Pemesanan Jasa Tukang Bangunan Berbasis Lokasi," J. Tek. Inform., vol. 15, no. 1, pp. 1-12, 2020.

[13] R. S. Pressman, "Rekayasa Perangkat Lunak Pendekatan Praktisi (Buku Satu)," Yogyakarta Andi, 2002.

[14] S. Mahankali and S. Chaudhary, "Blockchain in education: a comprehensive approachutility, use cases, and implementation in a university," in Blockchain Technology Applications in Education, IGI Global, 2020, pp. 267-293.

[15] N. Lutfiani, E. P. Harahap, Q. Aini, A. D. A. R. Ahmad, and U. Rahardja, "Inovasi Manajemen Proyek I-Learning Menggunakan Metode Agile Scrumban," InfoTekJar J. Nas. Inform. dan Teknol. Jar., vol. 5, no. 1, pp. 96-101, 2020.

[16] Adiyanto and R. Febrianto, "Authentication Of Transaction Process In E-marketplace Based On Blockchain technology," Aptisi Trans. Technopreneursh., vol. 2, no. 1, pp. 6874, 2020, doi: https://doi.org/10.34306/att.v2i1.71.

[17] U. Rahardja, N. Lutfiani, and A. Yolandari, "Penerapan Viewboard Informatif Pada Asosiasi Perguruan Tinggi Swasta Indonesia Dalam Era Industri 4.0," Technomedia J., vol. 3, no. 2, pp. 224-234, 2019.

[18] D. M. Khairina, D. Ivando, and S. Maharani, "Implementasi Metode Weighted Product Untuk Aplikasi Pemilihan Smartphone Android," J. Infotel, vol. 8, no. 1, pp. 16-23, 2016.

[19] S. LUMBANGAOL, "SISTEM INFORMASI PENENTUAN PEKERJA JASA KONTRAKTOR PADA PT. SUBUR SARI LASTDERICH," 2017.

[20] M. F. Asyhary, "TA: Rancang Bangun Aplikasi Jasa Bangunan Berbasis Web (Studi Kasus: CV Tirto Ardhi)." Institut Bisnis dan Informatika Stikom Surabaya, 2019.

[21] C. Lodigiani et al., "Venous and arterial thromboembolic complications in COVID-19 patients admitted to an academic hospital in Milan, Italy," Thromb. Res., vol. 191, pp. 9$14,2020$.

[22] T. Hariguna, E. P. Harahap, and S. Salsabila, "Implementation of Business Intelligence Using Highlights in the YII Framework based Attendance Assessment System," Aptisi Trans. Technopreneursh., vol. 1, no. 2, pp. 109-116, Aug. 2019, doi: 10.34306/att.v1i2.67.

[23] H. Henderi, S. R. Zuliana, and R. A. Pradana, "Periodic Data Analysis and Forecasting As An Overview of Future Management Economics," Aptisi Trans. Manag., vol. 3, no. 1, pp. 73-83, 2019.

[24] S. Saiful and A. Ambarita, "Pembuatan Aplikasi Web Pencarian Jasa Pembantu Rumah Tangga (PRT) Dikota Ternate," IJIS-Indonesian J. Inf. Syst., vol. 2, no. 2, 2017.

[25] I. Handayani, Q. Aini, and N. Sari, "Pemanfaatan Sistem iJC Berbasis OJS Sebagai Media E-Journal Pada STISIP YUPPENTEK," Technomedia J., vol. 2, no. 2, pp. 94-106, 2018.

[26] B. Djatmiko, M. Galinium, and N. Lutfiani, "The Role of a Variety of Research Studies on Problem Management," Aptisi Trans. Manag., vol. 2, no. 1, pp. 9-19, 2018.

[27] A. Williams and E. Dolan, "Application of Blockchain Technology in e-LoA Technopreneurship Journal," Aptisi Trans. Technopreneursh., vol. 2, no. 1, pp. 98-103, 
2020, doi: https://doi.org/10.34306/att.v2i1.74.

[28] L. Sathler, "For an Open Innovation Platform Dedicated to Education: A Blockchain Approach," in Blockchain Technology Applications in Education, IGI Global, 2020, pp. 153-169.

[29] A. Ameli, U. Hasanah, H. Rahman, and A. M. Putra, "Analisis keefektifan pembelajaran online di masa pandemi COVID-19," Mahaguru J. Pendidik. Guru Sekol. Dasar, vol. 2, no. 1, pp. 28-37, 2020.

[30] S. Subijanto, "Peran Negara dalam Hubungan Tenaga Kerja di Indonesia," J. Pendidik. Dan Kebud., vol. 17, no. 6, pp. 705-718, 2011.

[31] A. S. Bein, Y. I. Graha, and A. P. Pangestu, "Pandawan Website Design Based Content Management System As Media E-commerce Transaction," Aptisi Trans. Technopreneursh., vol. 2, no. 1, pp. 87-97, 2020, doi: https://doi.org/10.34306/att.v2i1.73.

[32] J. Hom, B. Anong, K. B. Rii, L. K. Choi, and K. Zelina, "The Octave Allegro Method in Risk Management Assessment of Educational Institutions," Aptisi Trans. Technopreneursh., vol. 2, no. 2, pp. 167-179, 2020.

[33] R. A. de FRETES, P. B. Santoso, R. Soenoko, and M. Astuti, "Strategi Perencanaan dan Pengembangan Industri Pariwisata dengan Menggunakan Metode SWOT dan QSPM (Studi Kasus Kecamatan Leitimur Selatan Kota Ambon)," Rekayasa Mesin, vol. 4, no. 2, pp. 109-118, 2013.

[34] I. Amsyar, E. Christopher, A. Dithi, A. N. Khan, and S. Maulana, "The Challenge of Cryptocurrency in the Era of the Digital Revolution: A Review of Systematic Literature," Aptisi Trans. Technopreneursh., vol. 2, no. 2, pp. 153-159, 2020. 